\title{
Blood metabolites and carcass characteristics of West African dwarf goats fed bread waste and Moringa oleifera leaf
}

*Ayandiran, S. K., Odeyinka, S. M. and Odedire, J. A. Department of Animal Sciences,

Obafemi Awolowo University, A234, Ile-Ife, Osun State. Nigeria.

Abstract

*Corresponding author: skayandiran@gmail.com

The study evaluated the blood metabolites and carcass quality of WAD goats fed bread waste and Moringa oleifera leaf. The goats ( $n=20$, 6-7 months old) were allotted to four treatments (5 goats per treatment) in a completely randomized design. The experiment lasted twenty weeks. Bread waste and Moringa oleifera were used to replace Corn bran and Brewer's dried grain $(w / w)$ in the compounded concentrate diets at 0, 25, 50 and 100\% to form treatments 1 , 2, 3 and 4, respectively. The goats fed diets T2, T3 and T4 had lower $(P<0.05)$ cholesterol levels $(52.83,45.11$, and $33.69 \mathrm{mg} / \mathrm{dL}$, respectively) than $T 1(54.89 \mathrm{mg} / \mathrm{dL})$. There was no significant difference $(P>0.05)$ among the means of the hematological indices across the treatments. However, the total protein of goats fed diets T2, T3 and T4 were higher $(P<0.05)$ than those on T1. The serum metabolite of the experimental goats indicated no significant difference $(P>0.05)$ in the albumin, aspartate aminotransferase $(A S T)$ and alkaline phosphate (ALP) contents while the total protein of goats fed diets T2, T3 and T4 (6.37, 6.39 and $6.53 \mathrm{~g} / \mathrm{dL}$ respectively) were higher $(P<0.05)$ than $T 1(4.66)$. The hot carcass weights of goats fed diets T4 $(4.56 \mathrm{~kg})$ and $T 3(4.45 \mathrm{~kg})$ were higher $(P<0.05)$ than those on diets $T 2$ $(4.21 \mathrm{~kg})$ and $T 1(4.01 \mathrm{~kg})$ whereas there was no significant difference $(P>0.05)$ in the dressing percentage and head weight. The goats fed diet T1 had highest $(P<0.05)$ value for the lungs, kidney and spleen weight when compared to diets T2, T3 and T4. It could be concluded that inclusion of bread waste and Moringa oleifera leaf in diet of WAD goats reduced blood cholesterol level, enhanced flesh deposition in the carcass and impacted no visible abnormalities on the visceral organs.

Keywords: blood, bread waste, carcass, Moringa oleifera, WAD goats

\section{Introduction}

Goat production constitutes very important part of ruminant livestock sub-sector in the Nigerian agricultural economy. They are one of the most important domesticated small ruminants with a population of 29.2 million in Nigeria (Ukanwoko et al., 2009). Thus, the potential of goat production in alleviating low animal protein intake by man in developing nation needs no emphasis (Ilori et al., 2013). However, the high cost of conventional feedstuffs as well as rapid decline in quality of forages especially during the dry season led to development of alternative feedstuffs in goat nutrition. Hence, it is necessary to turn attention to the utilization of agro-industrial by products and forage legumes particularly those that are inexpensive and are locally available all year round as livestock feeds. Bread is one of the most widely consumed food products in the world and bread making technology is probably one of the oldest technologies known (Selomulyo and Zhou, 2007). In Nigeria, bread is produced from wheat flour, sugar, vegetable fat, skimmed milk powder, salt, butter, flour and other ingredients, depending on the maker. It is rich in energy, low in fibre but high in vitamin (Al-Tulaihan et al., 2004). Moringa oleifera commonly called horse radish tree is an inexpensive forage protein source for livestock feeding (Sarwatt et al. 2004, Odeyinka et al. 2008). Though literatures revealed that bread waste and Moringa 


\section{Blood metabolites and carcass characteristics of West African dwarf goats}

possess excellent nutritional qualities, limited information is available on the inclusion of both as energy and protein sources, respectively in diets of goats. Therefore, the study examined the blood metabolites and carcass quality of WAD goats fed bread waste and Moringa oleifera leaf.

\section{Materials and methods}

Twenty West African dwarf goats (6-7 weeks old) of both sexes were used in this experiment. They were randomly allotted to four treatments in a Completely Randomized Design. The goats in each treatment (five goats) were housed together in a slated floor pens at the Sheep and Goat Unit. Bread waste was collected, oven dried, packaged and stored for subsequent use. Fresh Moringa oleifera leaves were obtained from Sheep and Goat Unit, Obafemi Awolowo University Teaching and Research farm, Ile Ife, Nigeria and air dried. Bread waste was used to replace Corn bran (w/w) as energy source while Moringa oleifera was used to replace Brewer's dried grain $(w / w)$ as a protein source. Four concentrate diets (T1, T2, T3 and T4) were compounded with inclusion of bread waste and Moringa leaf at 0, 25, 50 and 100\%, respectively (Table 1) which were fed to the goats at $3 \%$ of their body weight. On the last day of the experiment, two sets of blood samples were taken from the goats using 5 $\mathrm{mL}$ syringe. One $\mathrm{ml}$ blood sample was collected into labeled sterile bottles containing anticoagulant free bottles, allowed to coagulate at room temperature and centrifuged at $3000 \mathrm{rpm}$ for 10 minutes. The serum concentration for cholesterol, aspartate aminotranferase (AST), alkaline phosphate (ALP) and albumin were determined using commercial laboratory kit (Randox Laboratories Ltd, U.K). The red blood cell (RBC), white blood cell (WBC) and the packed cell volume (PCV) were determined using the method of Adedapo et al. (2007). Two goats per treatment were slaughtered by severing both the jugular veins and carotid arteries at the atlanto-occipital arhuculation (Okah, 2006). Data obtained were subjected to analysis of variance procedure of General Linear Model and the Duncan's New Multiple Range Test option of SAS (2008) was used for mean separation.

Table 1: Gross composition of experimental diets for the WAD goats

\begin{tabular}{|c|c|c|c|c|}
\hline Ingredient (\%) & $\mathrm{T} 1$ & $\mathrm{~T} 2$ & $\mathrm{~T} 3$ & $\mathrm{~T} 4$ \\
\hline Corn bran & 40.00 & 30.00 & 20.00 & - \\
\hline Brewer's dried grain & 40.00 & 30.00 & 20.00 & - \\
\hline Bread waste & - & 10.00 & 20.00 & 40.00 \\
\hline Moringa oleifera & - & 10.00 & 20.00 & 40.00 \\
\hline Palm kernel cake & 16.00 & 16.00 & 16.00 & 16.00 \\
\hline Bone meal & 3.00 & 3.00 & 3.00 & 3.00 \\
\hline $\begin{array}{l}\text { Vitamin/mineral } \\
\text { premix }\end{array}$ & 0.50 & 0.50 & 0.50 & 0.50 \\
\hline Salt & 0.5 & 0.5 & 0.5 & 0.5 \\
\hline
\end{tabular}

\section{Results and discussion}

There was significant difference $(\mathrm{p}<0.05)$ in serum cholesterol level of the experimental animals (Table 2). The animals fed diets containing bread waste and M. oleifera (T2, T3 and T4) had lower $(\mathrm{p}<0.05)$ cholesterol levels than $\mathrm{T} 1$, but there were no significant differences $(p>$ 0.05 ) among the means of the haematological indices (Packed cell volume, White blood cells and Red blood cells) across the treatments. The serum 


\section{Ayandiran, Odeyinka and Odedire}

metabolites of the experimental goats indicated no significant differences $(p>0.05)$ in the albumin, aspartate aminotransferase (AST) and alkaline phosphate (ALP) contents except for the total protein which were higher $(\mathrm{p}<0.05)$ in goats on T2, T3 and T4 compared to those on T1. Cholesterol is conventionally used for diagnosing human and domestic animal's hepatic damage (Silanikove and Tiomkin, 1992). The blood cholesterol of the goats in this study was lower than 56.80 - $103.90 \mathrm{mg} / \mathrm{dL}$ reported by Yusuf et al. (2012). It was observed that the blood cholesterol level of the animals fed diets containing bread waste and M. oleifera was far below the normal blood cholesterol values of $65-136 \mathrm{mg} / \mathrm{dL}$ reported by Merck (2011) hence indicating Moringa oleifera as a potent hypocholesterolemic agent, which agreed with the submission of Esonu et al. (2001) that haematological constituents reflect the physiological responsiveness of the animal to its internal and external environments (including feed and feeding). The packed cell volume in this present study was similar $(28.80-35.60 \%)$ to the values reported by Ayandiran et al. (2012) but lower than $34.00-37.00 \%$ reported by Okah et al. (2014). The red blood cell and the white blood cell counts were higher than the reported values of $8.1-$ $9.7 \times 10^{6}$ and $5.5-8.7 \times 10^{3}$ respectively by Fayomi et al. (2014). However, the values of Packed Cell Volume (PCV), Red Blood Cell (RBC) and White Blood Cell (WBC) obtained in this study were within normal physiological ranges $(27.0-45.0 \%, 9.0$ $15.0 \times 10^{6}$ and $4.0-12.0 \times 10^{3}$, respectively) reported by Jain (1993). The total protein observed for WAD goats fed diets T2, T3 and T4 in this study was within the range of $6.1-7.5 \mathrm{~g} / \mathrm{dL}$ reported by Merck (2011) whereas significantly lower total protein of goats fed T1 diet is an indication of the relatively poor protein quality of the diet, the level and availability of the dietary protein (Olafadehan, 2011). The albumin level of goats in this study was lower than $3.90-4.45 \mathrm{u} / \mathrm{L}$ reported by Yusuf et al. (2012) but similar to that obtained by Oyebanji and Ayandiran (2014). All the experimental goats were within the range of $2.7-4.4 \mathrm{~g} / \mathrm{dL}$ for globulin (Merck, 2011). Serum AST, ALP, albumin and total protein levels are known to be useful in assessing the functional integrity of the liver (Baez et al., 2007). Differences in serum biochemical parameters may be caused by nutrition, environment and hormonal factors (Chineke et al., 2002).

Table 2: Haematological and serum metabolites of the WAD goats

\begin{tabular}{lcccccc}
\hline Parameter & T1 & T2 & T3 & T4 & SEM & PROB. \\
\hline Cholesterol $(\mathrm{mg} / \mathrm{dL})$ & $54.89^{\mathrm{a}}$ & $52.83^{\mathrm{a}}$ & $45.11^{\mathrm{b}}$ & $33.69^{\mathrm{c}}$ & 5.01 & 0.04 \\
Packed cell volume $(\%)$ & 35.33 & 31.83 & 32.67 & 33.67 & 3.16 & 0.38 \\
Red blood cell $\left(10^{6}\right)$ & 13.47 & 12.80 & 12.20 & 12.47 & 1.08 & 0.73 \\
White blood cell $\left(10^{3}\right)$ & 10.07 & 10.00 & 11.13 & 11.33 & 0.56 & 0.20 \\
Total protein $(\mathrm{g} / \mathrm{dL})$ & $4.66^{\mathrm{b}}$ & $6.37^{\mathrm{a}}$ & $6.39^{\mathrm{a}}$ & $6.53^{\mathrm{a}}$ & 0.26 & 0.02 \\
Albumin $(\mathrm{g} / \mathrm{dL})$ & 2.96 & 2.65 & 2.72 & 3.07 & 0.09 & 0.52 \\
Globulin $(\mathrm{g} / \mathrm{dL})$ & $1.70^{\mathrm{b}}$ & $3.72^{\mathrm{a}}$ & $3.28^{\mathrm{a}}$ & $3.46^{\mathrm{a}}$ & 0.35 & 0.05 \\
AST $(\mathrm{g} / \mathrm{dL})$ & 17.73 & 17.41 & 17.34 & 18.09 & 1.22 & 0.21 \\
ALP $(\mathrm{g} / \mathrm{dL})$ & 4.02 & 3.92 & 3.76 & 4.10 & 0.32 & 0.51 \\
abc $:$ Means in a row with different superscripts differ significantly (p<0.05) & & & & \\
AST: Aspartate amin otransferase, ALP: Alkaline phosphate & & & & \\
T1: 0\% substitution level of BW and MO, T2: $25 \%$ substitution level of BW and MO & & & \\
T3: $50 \%$ substitution level of BW and MO, T4: $100 \%$ substitution level of BW and MO & & &
\end{tabular}




\section{Blood metabolites and carcass characteristics of West African dwarf goats}

There was significant difference $(\mathrm{p}<0.05)$ in the carcass quality parameters of goats fed bread waste and $M$. oleifera. The hot carcass weight of animals fed diets $\mathrm{T} 3$ and T4 were significantly higher $(\mathrm{p}<0.05)$ than animals on diets $\mathrm{T} 1$ and $\mathrm{T} 2$ whereas there was no significant difference $(p>0.05)$ in the percentage dressed and head weight. The neck value was significantly highest in animals fed diet $\mathrm{T} 4$, followed by $\mathrm{T} 1$ then $\mathrm{T} 2$ and $\mathrm{T} 3$ which were significantly the same. Furthermore, the shoulder weight was higher $(\mathrm{p}<0.05)$ in animals fed diet $\mathrm{T} 1$ than T2, T3 and T4. The diets T1 and T2 were comparable $(p>0.05)$ in the feet weight but significantly higher than T3 and T4 while the skin percentage followed similar trend as the shoulder weight. However, animals fed T4 diet had significantly highest $(p<0.05)$ loin weight than T3, T2 and the least T1. There was significant difference $(p<0.05)$ in the visceral organs of animals fed the experimental diets. The liver weight was significantly highest $(p<0.05)$ in diet T1, followed by T2, T3 and T4. Moreover, diets T4 and T3 had significantly highest $(\mathrm{p}<0.05)$ heart weight than diets T2 and T1 . However, the animals fed diet $\mathrm{T} 1$ had significant highest $(\mathrm{p}<0.05)$ value for the lungs, kidney and spleen weights than diets T2, T3 and T4 containing bread waste and
M. oleifera whose values were significantly similar throughout the treatments. The carcass and cut parts values of animals depend on how adequately the animals were able to utilize nutrients in feed to synthesize body tissues (Okah et al., 2014). There was no significant difference in the means of the dressing percentage of animals in this study as also reported by Simela et al. (2011). However, the value in this study was lower than $46.54 \%$ reported by Alkass et al. (2014) but comparable to $40.56-43.28 \%$ obtained by Odoemelam et al. (2014). The shoulder and leg in this present experiment percentage was relatively similar to $18.05-$ $10.74 \%$ and $9.20-11.69 \%$ recorded respectively by Okah et al. (2014) but lower than the values reported by Odoemelam et al. (2014). The loin percentage was comparable to $8.05-13.15 \%$ obtained by Okah et al. (2014). Moreover, the skin was also within the range $9.73-13.14 \%$ reported by Odoemelam et al. (2014). The percentage of all internal organs in this study was higher than values reported by Okah et al. (2014) for WAD buck fed differently processed poultry droppings. The relative organ weights (liver, lungs, kidney and spleen) were significantly higher in the control diet (T1). This shows that substitution of bread waste and $M$.

Table 3: Carcass quality of goats fed the experimental diets

\begin{tabular}{lcccccc}
\hline Parameter & T1 & T2 & T3 & T4 & SEM & PROB. \\
\hline Slaughter weight (kg) & 9.88 & 10.87 & 10.63 & 11.38 & 0.37 & 0.25 \\
Hot carcass (kg) & $4.01^{\mathrm{b}}$ & $4.21^{\mathrm{b}}$ & $4.45^{\mathrm{a}}$ & $4.56^{\mathrm{a}}$ & 0.08 & 0.01 \\
Dressing (\%) & 41.12 & 39.66 & 41.66 & 40.14 & 0.36 & $<0.0001$ \\
Head (\%) & 21.41 & 21.42 & 19.74 & 20.27 & 0.31 & 0.14 \\
Neck (\%) & $8.47^{\mathrm{b}}$ & $7.65^{\mathrm{c}}$ & $7.67^{\mathrm{c}}$ & $8.91^{\mathrm{a}}$ & 0.21 & $<0.0001$ \\
Shoulder (\%) & $11.00^{\mathrm{a}}$ & $10.06^{\mathrm{b}}$ & $9.50^{\mathrm{b}}$ & $9.70^{\mathrm{b}}$ & 0.12 & 0.05 \\
Feet (\%) & $8.28^{\mathrm{a}}$ & $7.78^{\mathrm{a}}$ & $7.07^{\mathrm{b}}$ & $6.82^{\mathrm{a}}$ & 0.22 & 0.01 \\
Loin (\%) & $10.50^{\mathrm{c}}$ & $10.00^{\mathrm{c}}$ & $11.90^{\mathrm{b}}$ & $12.65^{\mathrm{a}}$ & 0.20 & $<0.0001$ \\
Liver (\%) & $5.29^{\mathrm{a}}$ & $3.78^{\mathrm{b}}$ & $3.47^{\mathrm{b}}$ & $2.92^{\mathrm{c}}$ & 0.33 & $<0.0001$ \\
Heart (\%) & $1.29^{\mathrm{c}}$ & $1.39^{\mathrm{b}}$ & $1.47^{\mathrm{a}}$ & $1.42^{\mathrm{a}}$ & 0.03 & $<0.0001$ \\
Lungs (\%) & $2.85^{\mathrm{a}}$ & $2.38^{\mathrm{b}}$ & $2.34^{\mathrm{c}}$ & $2.40^{\mathrm{b}}$ & 0.08 & $<0.0001$ \\
Kidney (\%) & $1.26^{\mathrm{a}}$ & $1.18^{\mathrm{ab}}$ & $1.17^{\mathrm{ab}}$ & $1.09^{\mathrm{b}}$ & 0.03 & 0.03 \\
Spleen (\%) & $1.40^{\mathrm{a}}$ & $0.67^{\mathrm{b}}$ & $0.61^{\mathrm{b}}$ & $0.59^{\mathrm{b}}$ & 0.13 & $<0.0001$ \\
abc :Means in a row with different superscripts differ significantly (p<0.05) & & & & \\
T1: $0 \%$ substitution level of BW and MO, T2: $25^{\circ}$ substitution level of BW and MO & & &
\end{tabular}




\section{Ayandiran, Odeyinka and Odedire}

oleifera leaf in the diets of WAD goats promoted the growth of somatic cells for flesh deposition, but discouraged the growth of visceral organs.

\section{Conclusion}

It could be concluded that inclusion of bread waste and Moringa oleifera leaf in the diet of WAD goats reduced blood cholesterol level, enhanced flesh deposition in the carcass and impacted no visible abnormalities on the visceral organs.

\section{References}

Adedapo, A. A., Omoloye, O. A. and Ohore, O. G. 2007. Studies on the toxicity of an aqueous extract of leaves of Abrus precatorius in rats. Onderstepoort Journal of Veterinary Research.74:31-36.

Alkass, J. E., Oray, K. A. D., Abdulla, M. K. 2014. Studies on growth, carcass traits and body composition of goats raised either in intensive or pasture conditions (1-growth performance and carcass traits). Journal of Biology, Agriculture and Healthcare. Vol.4 (10): 45-53

Al-Tulaihan, A. A., Najib, $\mathrm{H}$ and Al-Eid, S. M. 2004. The nutritional evaluation of locally produced dried bakery waste (DBW) in the broiler diets. Pakistan Journal of Nutrition. 3 (5): 294-299.

Ayandiran, S. K., Odeyinka, S. M. and Makinde, O.A. 2012. Utilization of wheat offal-carried pineapple waste meal in the diet of West African Dwarf goats. Bulletin of Animal Health and Production in Africa. 60 (4): 501-510

Baez, R., Lopes, M.T., Salas, C.E and Hernandez, M. 2007. In-vivo antitumoral activity of Stem pineapple (Ananas comosus) bromelain. Planta Med. 73 (13):13.
77-83.

Chineke, C. A., Adeniran, F. A., Olugun, A. G., Ikeobi, C. O. N, and Oseni, O.A. 2002. Analysis of some serum biochemical parameters in New Zealand Rabbit and their crosses. In: VA Aletor, GE Onibi (Eds) Proceedings of 27th Annual Conference of Nigeria Society of Animal Production. March 17-21, 2002. FUT. Akure, Nig. pp 5-7.

Esonu, B. O., Emenalom, O. O., Udedibie, A. B. I., Berbert, U., Ekpor, C. F., Okoli, E. C. and Iheukwumere, F. C. 2001 . Performance and chemistry of weaner pigs fed raw mucuna bean (Velvet bean) meal. Tropical Animal Production and Investment. 4:4954.

Fayomi, A., Ahmed, A., Musa, U., Salami-Shinaba, J. O., Ogedegbe, S. A. and Akanni, K. 2014. Moringa multi-nutrient blocks: formulation, Production, and feeding trial under a tropical Environment. International Journal of Science, Environment and Technology. 3 (1) 67 - 84.

Ilori, H. B., Salami, S. A., Majoka, M. A. and Okunlola D. O. 2013. Acceptability and nutrient digestibility of West African Dwarf goat fed different dietary inclusion of Baobab (Adansonia digitata). ISOR Journal of Agriculture and Veterinary Science. 6(3) 22-26.

Jain N. C. 1993. Essentials of veterinary haematology Lea and Febiger Publishers Malvern, Pennysylvania U.S.A.

Merck 2011. Merck Sharp and Dohme Corp., a subsidiary of Merck \& Co., Inc. Whitehouse Station, NJ, USA.

Odeyinka, S. M., Oyedele, O. J., Adeleke, T. O. and Odedire, J. A. 2008. 


\section{Blood metabolites and carcass characteristics of West African dwarf goats}

Reproductive performance of rabbits fed moringa oleifera as a replacement for Centrosema pubescens. In: 9th World Rabbit Congress - June 10 - 13, 2008, Verona, Italy.

Odoemelam, V. U., Ahamefule, F. O., Ahiwe, E. U., Ekwe, C. C. and Obi, J. I. 2014. Carcass yield, organ characteristics and economics of West African Dwarf bucks fed Panicum maximum supplemented concentrate containing Bambara nut (Vigna subterranean) meal. Nigerian Journal of Agriculture, Food and Environment. 10(4):1824.

Okah, U. 2006. Performance of sheep fed varying levels of pigeon pea (cajanu cajan) seed in the concentrate diets. Ph.D. Dissertation. Micheal Okpara University of Agriculture, Umudike, Abia State, Nigeria.

Okah, U., Anokwuru, R. K and Onyearu, V. O. 2014. Performance of (WAD) bucks fed differently processed poultry droppings. Nigerian Journal of Animal Production. 41: $146-156$

Olafedehan, C. O., Obun, A. M., Yusuf, M. K., Adewumi, O. O. Olafedehan, A. O., Awofolaji, A. O. and Adeniji, A. A. 2010. Effects of residual cyanide in processed cassava peel meals on haematological and biochemical indices of growing rabbits. Proceedings of the 35th Annual Conference of the Nigerian Society for Animal Production. 212.

Oyebanji, B. O. and Ayandiran, S. K. 2014. Effect of feeding pineapple waste on haematological and biochemical parameters of West African Dwarf goats. Journal of Agriculture and Rural
Developmnet. 13:28-38.

SAS, (2008). SAS Users Guide Statistics, SAS inc. Cary, North Califonia, 2008 edition.

Sarwatt, S. V., Kapange, S. S. and Kakengi, A. M. 2002. Substituting sunflower seed cakewith Moringa oleifera leaves as supplemental goat feed in Tanzania. Agro-forestry systems. 56: 241-247.

Selomulyo, V. O. and Zhou, W. 2007. Frozen bread dough: Effects of freezing storage and dough improvers. Journal of Cereal Sciience. 45: 1-17.

Silanikove, N and Tiomikin, D. 1992. Toxicity induced by poultry litter consumption effect on measurement reflecting liver function in beef cows. Animal Production. 54:203209.

Simela, L., Webb, E. C. and Bosman, M. J. C. 2011. Live animal and carcass characteristics of South African indigenous goats. South African Journal of Animal Science. 41 (1). http://www.sasas.co.za

Ukanwoko, A. I., Ibeawuchi, J. A., Ukakchukwu, S. N. 2009. Growth performance and carcass characteristics of West African Dwarf Goats fed cassava a leaf meal based diet. Proceeding of 34th Annual conference of Nigeria Society for Animal Production. University of Uyo. Pp 476-479.

Yusuf., A. O., Oyebanji, O. A., Yusuf, D. A., Ekunseitan, K. A., Adeleye, O. S., Sowande and Fasae, O.A. 2012. Blood profile of West African Dwarf goats fed Panicum maximum supplemented with newbouldia laevis leaves. Bulletin of Animal Health Production Africa. 60: 481 490.

Received: 12 $2^{\text {th }}$ August, 2018

Accepted: $20^{\text {th }}$ February, 2019 